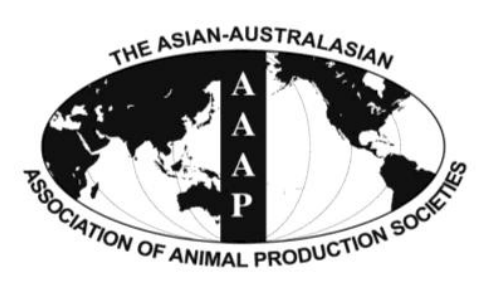

\title{
Evaluation of Various Packaging Systems on the Activity of Antioxidant Enzyme, and Oxidation and Color Stabilities in Sliced Hanwoo (Korean Cattle) Beef Loin during Chill Storage
}

\author{
Sun Moon Kang, Geunho Kang, Pil-Nam Seong, Beomyoung Park, and Soohyun Cho* \\ Animal Products Research and Development Division, National Institute of Animal Science, \\ Rural Development Administration, Suwon 441-706, Korea
}

\begin{abstract}
The effects of various packaging systems, vacuum packaging (VACP), medium oxygen-modified atmosphere packaging $\left(50 \% \mathrm{O}_{2} / 20 \% \mathrm{CO}_{2} / 30 \% \mathrm{~N}_{2}\right.$, MOMAP), MOMAP combined with vacuum skin packaging (VSP-MOMAP), high oxygen-MAP (80\% $\mathrm{O}_{2} / 20 \% \mathrm{CO}_{2} / 0 \% \mathrm{~N}_{2}$, HOMAP), and HOMAP combined with VSP (VSP-HOMAP), on the activity of antioxidant enzyme, and oxidation and color stabilities in sliced Hanwoo (Korean cattle) beef loin were investigated at $4{ }^{\circ} \mathrm{C}$ for $14 \mathrm{~d}$. Higher $(\mathrm{p}<0.05)$ superoxide dismutase activity and total reducing ability were maintained in VSP-MOMAP beef than in HOMAP beef. Lipid oxidation (2-thiobarbituric acid reactive substances, TBARS) was significantly $(\mathrm{p}<0.05)$ retarded in MOMAP, VSP-MOMAP, and VSP-HOMAP beef compared with HOMAP beef. Production of nonheme iron content was lower $(\mathrm{p}<0.05)$ in VSP-MOMAP beef than in HOMAP beef. Red color $\left(\mathrm{a}^{*}\right)$ was kept higher $(\mathrm{p}<0.05)$ in VSP-MOMAP beef compared with MOMAP, HOMAP, and VSP-HOMAP beef. However, VACP beef was found to have the most positive effects on the antioxidant activity, oxidation and red color stabilities among the various packaged beef. These findings suggested that VSP-MOMAP was second to VACP in improving oxidation and color stabilities in sliced beef loin during chill storage. (Key Words: Packaging, Antioxidant, Oxidation Stability, Color, Beef Loin, Hanwoo)
\end{abstract}

\section{INTRODUCTION}

Packaging system is one of the important factors postharvest for maintenance of fresh appearance, delay of deterioration process, and enhancement of shelf-life during storage of raw meat (Jayasingh et al., 2001; Lagerstedt et al., 2011). Meat packaging technology has been consistently advanced with improvement of consumer's practical sense for meat quality. Now, vacuum packaging (VACP), modified atmosphere packaging (MAP), and vacuum skin packaging (VSP) have been utilized in the meat industry.

The VACP, the most popular packaging system for aging of fresh meat, with little oxygen environment inside the pack, has a beneficial effect on prevention of oxidation, flavor preservation, and inhibition of microbial growth but

\footnotetext{
* Corresponding Author: Soohyun Cho. Tel: +82-31-290-1703, Fax: +82-31-290-1697, E-mail: shc0915@korea.kr

Submitted Feb. 24, 2014; Revised Apr. 13, 2014; Accepted Jun. 9, 2014
}

gives rise to unacceptable color due to development of deoxymyoglobin and deformation of shape (Borch et al., 1996; Santos et al., 2005; Troy and Kerry, 2010; Avilés et al., 2014). The VSP improves the appearance together with color stability and slows the growth rate of microorganisms compared to VACP (Barros-Velázquez et al., 2003; Vázquez et al., 2004). The MAP has the advantages of better color stability and microorganism control owing to filling with oxygen $\left(\mathrm{O}_{2}\right)$ and carbon dioxide $\left(\mathrm{CO}_{2}\right)$ inside the pack (Lopez-Lorenzo et al., 1980; Gill and Harrison, 1989). In retail fresh meat, high oxygen-MAP (70\% to $80 \% \mathrm{O}_{2} / 20 \%$ to $30 \% \mathrm{CO}_{2}$; HOMAP) is the most effective in stabilizing color but entails the oxidative deterioration (Jakobsen and Bertelsen, 2000; Lund et al., 2007b). Recently, the more advanced type of HOMAP combined with VSP has been industrially developed for the purpose of extending shelflife of fresh meat as compared to HOMAP alone.

The oxidation stability of components, such as fat, protein and myoglobin, in the meat, plays a major part in 
preserving the meat quality. During storage of meat, lipid oxidation, which is originated by contact with oxygen, creates free radicals contributing to the oxidation of myoglobin and protein (Xiong, 2000; Faustman et al., 2010). This oxidation process negatively affects the quality of meat. The accumulation of metmyoglobin on the surface of meat causes the consumer's refusal to purchase and economic loss of retail (Smith et al., 2000). The oxidation of meat protein incurs the development of carbonyls, hydroperoxides, and sulfoxides, deterioration of texture, and decline in water-holding capacity (Davies and Dean, 2003; Morzel et al., 2006). Thus, to keep the quality of the raw meat, a decrease in oxidation stability should be prevented as much as possible.

Not only in the tissues of living animals but also in muscles post-slaughter, enzymatic and non-enzymatic antioxidant systems subsist to defend against attacks of free radicals (Chan and Decker, 1994). Several studies have reported the inhibitory effect of the enzymatic antioxidant system, such as catalase, superoxide dismutase (SOD), and glutathione peroxidase (GPx), on the lipid oxidation of meat (Mei et al., 1994; Lee et al., 1996). The endogenous antioxidant enzymes in the meat are affected by various factors, such as feed, pre-slaughter stress, packaging and processing, etc. (Mercier et al., 2004; Chen et al., 2010; Gheisari and Motamedi, 2010; Kang et al., 2012). Particularly, in a previous study on the beef packaged with modified atmosphere, Kang et al. (2012) found that increasing $\mathrm{O}_{2}$ concentration accelerated the lipid oxidation and browning of color due to a decrease in the activity of some antioxidant enzyme. However, there have been few researches reported on the comparison of antioxidant enzymes, lipid and protein oxidation, and color among VACP, $\mathrm{O}_{2}$-MAP alone, and $\mathrm{O}_{2}$-MAP combined with VSP during storage. This research was, therefore, conducted to estimate the activities of antioxidant enzymes, and oxidation and color stabilities in sliced Hanwoo (Korean cattle) beef loin in various packaging systems during chill storage.

\section{MATERIALS AND METHODS}

\section{Reagents and chemicals}

Experimental deionized water (DW) was made using a Milli-Q Water Purifier (Millipore SAS, Molsheim, Alsace, France). Ethyl alcohol, ethyl acetate, and chloroform were purchased from J. T. Baker (Phillipsburg, NJ, USA). Thiobarbituric acid (TBA) was obtained from Alfa Aesar (Ward Hill, MA, USA). The 2,4-dinitrophenylhydrazine (DNPH), ammonium sulfamate, $\beta$-nicotinamide adenine dinucleotide $2^{\prime}$-phosphate reduced ( $\beta$-NADPH), cacodylic acid, diethylenetriaminepentaacetic acid (DTPA), ethylenediaminetetraacetate (EDTA), glutathione reductase from Baker's yeast (GSH-R), guanidine-HCl, L-glutathione reduced (GSH), lead acetate, neocuproine, 3-(2-pyridyl)5,6-diphenyl-1,2,4-triazine- $p, p^{\prime}$-disulfonic acid (ferrozine), pipes, potassium ferricyanide, pyrogallol, bovine serum albumin (BSA), trichloroacetic acid (TCA), and trizma base were purchased from Sigma-Aldrich Co. LLC. (St. Louis, MO, USA).

\section{Sample preparation and experimental design}

Hanwoo (Korean cattle; steer) beef loins (carcass quality grade of 1) at d 2 post-slaughter were purchased from a local market and then aged under VACP at $2^{\circ} \mathrm{C}$ for 7 $\mathrm{d}$ before trimming to conform with the commercial distribution condition. The sliced lean meat (about $1 \mathrm{~cm}$ thickness) were randomly assigned to five different types of packaging treatments; i) vacuum packaging (VACP), ii) medium oxygen-modified atmosphere packaging (50\% $\mathrm{O}_{2} / 20 \% \quad \mathrm{CO}_{2} / 30 \% \quad \mathrm{~N}_{2} ;$ MOMAP) alone, iii) MOMAP combined with vacuum skin packaging (VSP-MOMAP), iv) HOMAP $\left(80 \% \quad \mathrm{O}_{2} / 20 \% \quad \mathrm{CO}_{2} / 0 \% \quad \mathrm{~N}_{2}\right)$ alone, or v) HOMAP combined with VSP (VSP-HOMAP). The beef of VACP treatment was placed into a seven-layered film (nylon/tie/linear low density polyethylene (LLDPE)/tie /nylon/tie/LLDPE; FoodSaver pouch, Rollpack Co., Ltd., Pyeongtaek, Gyeonggi, Korea) and packaged using a VACP machine (CD-120, Webomatic Maschinenfabrik GmbH, Bochum, North Rhine-Westphalia, Germany). Using a MAP machine (MAP-RT1, HyperPac Co., Hwaseong, Korea) equipped with a gas mixer (MAP Mix 9001 ME, PBI Dansensor A/S, Ringsted, Sjælland, Denmark), the packs of MOMAP and HOMAP treatments were applied to vacuum, filled with mixed gases, and then sealed with an oxygen barrier film (max. $\mathrm{O}_{2}$ transmission rate: $0.002 \mathrm{cc} / \mathrm{cm}^{2} \cdot 24 \mathrm{~h}$ at $4.4^{\circ} \mathrm{C}$, relative humidity $(\mathrm{RH}) 100 \%$, max. moisture vapor transmission rate: $0.39 \mathrm{mg} / \mathrm{cm}^{2} \cdot 24 \mathrm{~h}$ at $4.4^{\circ} \mathrm{C}, \mathrm{RH}$ 100\%; Lid 1050, Cryovac Sealed Air Corp., Duncan, SC, USA) following the placement of beef onto a polystyrene barrier foam tray (max. oxygen transmission rate: 0.1 $\mathrm{cc} / \mathrm{cm}^{2} \cdot 24 \mathrm{~h}$ at $23^{\circ} \mathrm{C}$, $\mathrm{RH} 0 \%$, max. moisture vapor transmission rate: $7.87 \mathrm{mg} / \mathrm{cm}^{2} \cdot 24 \mathrm{~h}$ at $38^{\circ} \mathrm{C}, \mathrm{RH} 100 \%$; SCB00-096, Cryovac Sealed Air Corp., USA). The beef of VSP-MOMAP and VSP-HOMAP treatments were placed into a tray and covered with a permeable intact film (100247492, Cryovac Sealed Air Corp., USA) by a VSP machine (VSP-S100, Samhwa Co., Hwaseong, Korea) before accomplishment of MAP. Packaged samples were then stored in a refrigerator (DS-95P, Dasol Scientific Co., Ltd., Hwaseong, Korea) at $4^{\circ} \mathrm{C}$ for $14 \mathrm{~d}$ and measurements were made on $\mathrm{d} 1,3,7,10$, and 14 .

\section{Determination of gas concentration}

The concentrations $(\%)$ of $\mathrm{O}_{2}$ and $\mathrm{CO}_{2}$ in MAP were confirmed by a portable gas analyzer (OxyBaby $\mathrm{M}+\mathrm{X}$ 
$\mathrm{O}_{2} / \mathrm{CO}_{2}$, Witt-Gasetechnik GmbH \& Co., KG, Witten, North Rhine-Westphalia, Germany). The relative percentage of nitrogen was calculated as $100-\left(\mathrm{O}_{2}[\%]+\mathrm{CO}_{2}[\%]\right)$.

\section{Antioxidant enzyme activity measurement}

Five grams of beef were homogenized with $20 \mathrm{~mL}$ of ice-cold $0.05 \mathrm{M}$ phosphate buffer (pH 7.0) using an UltraTurrax (T25 Digital, Ika Werke GmbH \& Co., KG, Staufen, Baden-Wüttenberg, Germany) at 13,500 rpm for $30 \mathrm{~s}$, centrifuged at $2^{\circ} \mathrm{C} / 1,000 \mathrm{~g}$ (Renerre et al., 1996; Avanti J-E Centrifuge, Beckman Coulter, Inc., Palo Alto, CA, USA) for $15 \mathrm{~min}$ and then filtered with a Whatman filter paper No. 1. Catalase (hydrogen peroxide: hydrogen peroxide oxidoreductase; E.C. 1.11.1.6) activity was analyzed with the method developed by Aebi (1983). The decomposition rate of $\mathrm{H}_{2} \mathrm{O}_{2}$ was measured at $240 \mathrm{~nm}$ at $25^{\circ} \mathrm{C}$ (ProteomeLab DU-800, Beckman Coulter, Inc., USA) for $30 \mathrm{~s}$ immediately after mixing $100 \mu \mathrm{L}$ of beef extracts with $29 \mathrm{mM} \mathrm{H} \mathrm{H}_{2} \mathrm{O}_{2}$ (in phosphate buffer, $\mathrm{pH}$ 7.0). The GPx (glutathione: hydrogen peroxide oxidoreductase; E.C. 1.11.1.9) activity was analyzed with the enzymatic procedure reported by Flohé and Günzler (1984). The oxidation rate of NADPH was measured at $340 \mathrm{~nm}$ at $25^{\circ} \mathrm{C}$ for $180 \mathrm{~s}$ following mixing $100 \mu \mathrm{L}$ of extracts with enzyme medium ( 1 mM EDTA-1 mM NaN ${ }_{3}-0.5$ units/mL GSH-R-1 mM GSH-0.15 mM $\beta$-NADPH-0.15 $\mathrm{mM} \mathrm{H}_{2} \mathrm{O}_{2}$ in phosphate buffer, $\mathrm{pH}$ 7.0). The SOD (superoxide: superoxide oxidoreductase; E.C. 1.15.1.1) activity was analyzed as described by Marklund (1986). The inhibition rate of pyrogallol (0.2 mM in tris-cacodylate-DTPA buffer, $\mathrm{pH} 8.2)$ autooxidation by $50 \mu \mathrm{L}$ of extracts was measured at $420 \mathrm{~nm}$ at $25^{\circ} \mathrm{C}$ for $120 \mathrm{~s}$. The activities of three antioxidant enzymes were computed with change in rates of absorbance values per min as unit enzyme/g meat.

\section{Measurement of total reducing ability}

Total reducing ability (TRA) was performed as described by Lee et al. (1981). Briefly, $2 \mathrm{~g}$ of samples were homogenized with $10 \mathrm{~mL}$ of ice-cold $25 \mathrm{mM}$ pipes buffer (pH 5.8) by a Polytron (PT-MR 2100, Kinematica AG, Littau, Luzern, Switzerland) at 13,500 rpm for $15 \mathrm{~s}$. Five milliliters of homogenates were mixed with $100 \mu \mathrm{L}$ of 0.04 $\mathrm{M}$ ammonium sulfamate, $200 \mu \mathrm{L}$ of $0.5 \mathrm{M}$ lead acetate, and $2.5 \mathrm{~mL}$ of $20 \%(\mathrm{w} / \mathrm{v}) \mathrm{TCA}$ and then made up to total volume of $10 \mathrm{~mL}$ with DW following incubation with $2 \mathrm{~mL}$ of $5 \mathrm{mM}$ potassium ferricyanide in an ice under the dark for $60 \mathrm{~min}$. Before filtration with a Whatman filter paper No. 42 , final mixtures were centrifuged at $2{ }^{\circ} \mathrm{C} / 3,000 \mathrm{~g}$ (Avanti J-20XP Centrifuge, Beckman Coulter, Inc., USA) for 10 $\mathrm{min}$ and then measured at $420 \mathrm{~nm}$. The TRA was expressed as absorbance value of sample against absorbance value of $1 \mathrm{mM}$ potassium ferricyanide (blank).

\section{2-Thiobarbituric acid reactive substances content analysis}

The 2-thiobarbituric acid reactive substances (TBARS) content was measured with the process previously reported by Sinnhuber and Yu (1977). The beef samples $(0.5 \mathrm{~g})$ were mixed with about $0.1 \mathrm{~g}$ of antioxidant mixture $(54 \%[\mathrm{w} / \mathrm{w}]$ propylene glycol-40\% [w/w] Tween 20-3\% [w/w] butylated hydroxytoluene- $3 \%[\mathrm{w} / \mathrm{w}]$ butylated hydroxyanisole, $3 \mathrm{~mL}$ of $1 \%(\mathrm{w} / \mathrm{v}) \mathrm{TBA}-0.3 \%(\mathrm{w} / \mathrm{v}) \mathrm{NaOH}$, and $17 \mathrm{~mL}$ of $2.5 \%$ (w/v) TCA-36 mM HCl, boiled at $100^{\circ} \mathrm{C}$ for $30 \mathrm{~min}$ and ice-cooled for $10 \mathrm{~min}$. Then, $5 \mathrm{~mL}$ of upper solutions were transferred to a conical tube and $3 \mathrm{~mL}$ of chloroform was added before centrifugation at $4^{\circ} \mathrm{C} / 3,000 \mathrm{~g}$ (Avanti J-E Centrifuge, Beckman Coulter, Inc., USA) for $30 \mathrm{~min}$. Absorbance values of supernatants were measured at 532 $\mathrm{nm}$ and converted into mg malonaldehyde (MA)/kg meat.

\section{Carbonyl content analysis}

Carbonyl content was analyzed according to the procedure described by Mercier et al. (1998). Two grams of samples were mixed with $20 \mathrm{~mL}$ of ice-cold $0.15 \mathrm{M} \mathrm{KCl}$ and filtered with a Whatman filter paper No. 1. One hundred microliters of extracts were incubated either with $0.5 \mathrm{~mL}$ of $0.2 \%(\mathrm{w} / \mathrm{v}) \mathrm{DNPH}$ (in $2 \mathrm{~N} \mathrm{HCl}$; for carbonyl content) or $2 \mathrm{~N} \mathrm{HCl}$ (for protein content) for 60 min under the dark, combined with $0.6 \mathrm{~mL}$ of $20 \%$ (w/v) TCA and placed on ice for $10 \mathrm{~min}$. Following centrifugation at $2^{\circ} \mathrm{C} / 3,000 \mathrm{~g}$ (Microfuge 22R Centrifuge, Beckman Coulter $\mathrm{GmbH}$, Krefeld, North Rhine-Westphalia, Germany) for 5 $\mathrm{min}$, the sediments were rinsed with ethyl acetate-ethyl alcohol (1:1) at three times, dried in a hood and then dissolved in $1 \mathrm{~mL}$ of guanidine- $\mathrm{HCl}(6 \mathrm{M}$ in $20 \mathrm{mM}$ potassium phosphate buffer, $\mathrm{pH} 6.5$ ). Absorbance values of mixtures measuring at 370 (DNPH-incubated) and 280 (HCl-incubated) $\mathrm{nm}$ were converted into nmol carbonyl/mg protein with standard curve of BSA and millimolar extinction coefficient $\left(22.0 \mathrm{mM}^{-1} \mathrm{~cm}^{-1}\right.$; Reznick and Packer, 1994) of protein hydrazones.

\section{Nonheme iron content measurement}

Nonheme iron content was quantified based on the ferrozine method developed by Carter (1971). One and half grams of samples were homogenized with $4.5 \mathrm{~mL}$ of icecold $0.1 \mathrm{M}$ citrate-phosphate buffer $(\mathrm{pH} \quad 5.5)$ and centrifuged at $2^{\circ} \mathrm{C} / 1,800 \mathrm{~g}$ for $10 \mathrm{~min}$. One milliliter of supernatants was mixed with $0.5 \mathrm{~mL}$ of $2 \%(w / v)$ ascorbic acid, incubated at $20^{\circ} \mathrm{C}$ to $22^{\circ} \mathrm{C}$ under the dark for $10 \mathrm{~min}$, and then combined with $0.5 \mathrm{~mL}$ of ice-cold $11.3 \%(\mathrm{w} / \mathrm{v})$ TCA before centrifugation at $2^{\circ} \mathrm{C} / 10,000 \mathrm{~g}$ for $10 \mathrm{~min}$. Final supernatants were reacted with $10 \%(w / v)$ ammonium acetate and ferroin color reagent for $10 \mathrm{~min}$ and spectrophotometrically measured at $562 \mathrm{~nm}$. The results were calculated with absorbance values of samples against 
blank and molar extinction coefficient $\left(28,000 \mathrm{M}^{-1} \mathrm{~cm}^{-1}\right)$ of iron-ferrozine complex as $\mu \mathrm{g} \mathrm{Fe/g} \mathrm{meat.}$

\section{Determination of instrumental meat color}

The determination of Commission Internationale de l'Eclairage (CIE) $a^{*}$ value was performed on the surface of samples by a chroma meter (CR-400, Konica Minolta Sensing, Inc., Tokyo, Honshu, Japan) calibrated with a white plate (illuminant $\mathrm{C}$; $\mathrm{L}^{*}=97.70, \mathrm{a}^{*}=-0.05$, and $\mathrm{b}^{*}=$ 1.94). The beef stored under VACP was determined after blooming for $30 \mathrm{~min}$ while the beef stored under other packaging systems was determined immediately after removal of film.

\section{Statistical analysis}

All data collected for the activities of catalase, GPx, and SOD, TRA, the contents of TBARS, carbonyl, and nonheme iron, and CIE a* value were analyzed by two-way analysis of variance using the general linear model procedure of SPSS (2011) program. As fixed factors, the effects of packaging system (VACP, MOMAP, VSPMOMAP, HOMAP, and VSP-HOMAP), storage time (d 1, 7, and 14 or $\mathrm{d} 1,3,7,10$, and 14), and their interaction (packaging system $\times$ storage time) on all variables were evaluated in our study. Duncan's multiple range test was carried out to compare significant $(\mathrm{p}<0.05)$ differences among mean values of variables in packaging systems within each storage time or in storage times within each packaging system, when significances of two main factors were presented.

\section{RESULTS AND DISCUSSION}

\section{Antioxidant enzyme activity}

Packaging system $(\mathrm{p}<0.001)$, storage time $(\mathrm{p}<0.001)$, and their interaction $(\mathrm{p}<0.05)$ had significant effects on the catalase activity in the sliced Hanwoo beef loin (Table 1).

Table 1. Effects of packaging system, storage time, and their interaction on the variables

\begin{tabular}{lccc}
\hline \multirow{2}{*}{ Variables } & \multicolumn{3}{c}{ Significance } \\
\cline { 2 - 4 } & $\begin{array}{c}\text { Packaging } \\
\text { system }\end{array}$ & Storage time & Interaction \\
\hline Catalase & $<0.001$ & $<0.001$ & 0.041 \\
GPx & 0.044 & $<0.001$ & $\mathrm{NS}$ \\
SOD & 0.001 & $<0.001$ & $\mathrm{NS}$ \\
TRA & $<0.001$ & $<0.001$ & $<0.001$ \\
TBARS & $<0.001$ & $<0.001$ & $<0.001$ \\
Carbonyl & 0.004 & $<0.001$ & 0.025 \\
CIE a* & $<0.001$ & $<0.001$ & $<0.001$ \\
Nonheme iron & 0.008 & $<0.001$ & 0.023 \\
\hline GPX, gla
\end{tabular}

GPx, glutathione peroxidase; NS, not significant; SOD, superoxide dismutase; TRA, total reducing ability; TBARS, 2-thiobarbituric acid reactive substances; CIE, Commission Internationale de l'Eclairage.
During $14 \mathrm{~d}$ of storage, a decrease $(\mathrm{p}<0.05)$ in catalase activity was observed in the sliced beef stored under VACP, MOMAP, and VSP-MOMAP (Figure 1). The sliced beef stored under VACP had higher $(\mathrm{p}<0.05)$ catalase activity
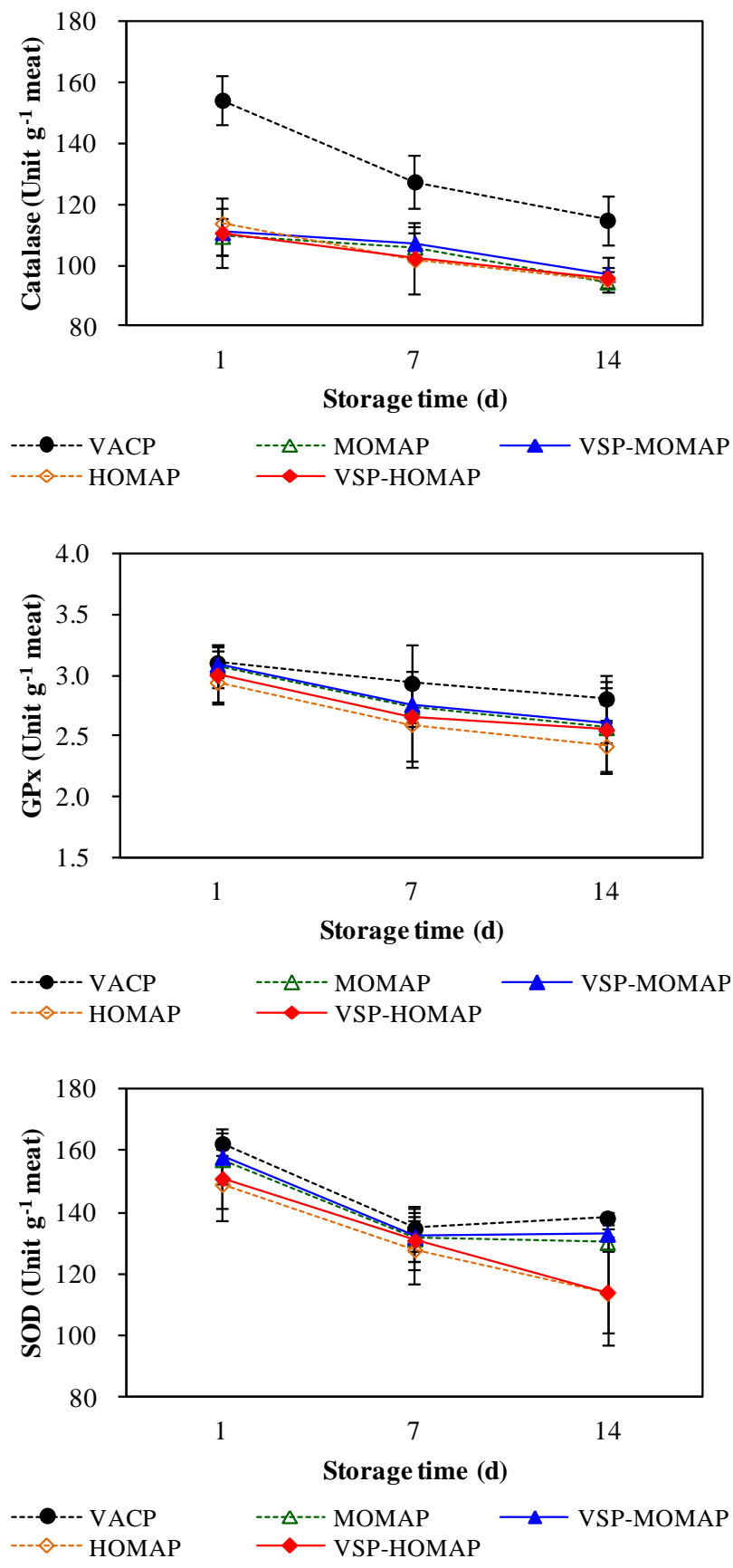

Figure 1. Antioxidant enzyme activity in sliced Hanwoo (Korean cattle) beef loin in various packaging systems for $14 \mathrm{~d}$ at $4^{\circ} \mathrm{C}$. Data are presented as means $\pm \mathrm{SD}$. GPx, glutathione peroxidase; SOD, superoxide dismutase; VACP, vacuum packaging; MOMAP, medium oxygen-modified atmosphere packaging $\left(50 \%\right.$ O $\mathrm{O}_{2} / 20 \%$ $\mathrm{CO}_{2} / 30 \% \mathrm{~N}_{2}$ ) alone; VSP-MOMAP, MOMAP combined with vacuum skin packaging; HOMAP, high oxygen-MAP $(80 \%$ $\mathrm{O}_{2} / 20 \% \quad \mathrm{CO}_{2} / 0 \% \quad \mathrm{~N}_{2}$ ) alone; VSP-HOMAP, HOMAP combined with VSP; SD, standard deviation. 
compared with the beef stored under MOMAP, VSPMOMAP, HOMAP, and VSP-MAP for $14 \mathrm{~d}$ of storage. However, there were not significant differences for catalase activity by both $\mathrm{O}_{2}$ concentration in MAP and combination with VSP. Whereas, the activities of GPx and SOD in the stored-sliced beef were influenced by both packaging system $(p<0.05$ and $p=0.001)$ and storage time $(p<0.001)$, there were no significant $(p>0.05)$ effects due to their interaction (Table 1). The activity of GPx decreased $(p<0.05)$ in the sliced beef stored under MOMAP, VSPMOMAP, and HOMAP during storage (Figure 1). At d 14, the sliced beef stored under VACP had higher $(\mathrm{p}<0.05)$ GPx activity than the beef stored under HOMAP. A decrease $(p<0.05)$ in SOD activity was indicated in the sliced beef stored under all packaging systems (Figure 1). Compared with the other packaging systems, the sliced beef stored under VACP had higher $(\mathrm{p}<0.05)$ SOD activity at $d 14$. At the same storage time, the sliced beef stored under both MOMAP and VSP-MOMAP had higher $(\mathrm{p}<0.05)$ SOD activity compared with the beef stored under both HOMAP and VSP-HOMAP. But combination with VSP did not influence GPX and SOD activities in the sliced beef at d 14 of storage. These results imply that higher $\mathrm{O}_{2}$ atmosphere in a packaging system decreased the activities of antioxidant enzymes in the stored-sliced beef. Previously, Kang et al. (2012) reported a similar finding which the activity of some antioxidant enzyme in the chopped beef was decreased by an increase in $\mathrm{O}_{2}$ concentration in MAP for $8 \mathrm{~d}$. This phenomenon may be partially due to decomposed or denatured antioxidant enzymes by oxidation promoted by

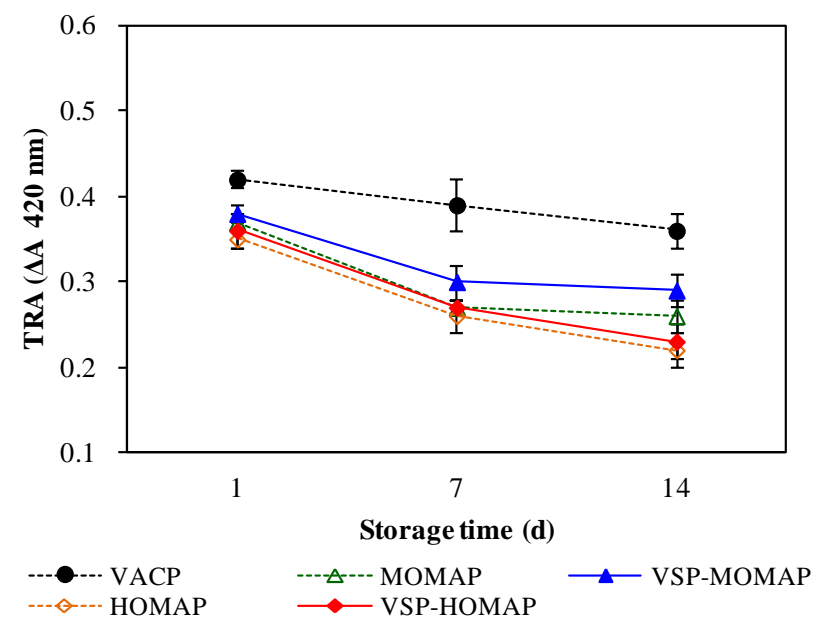

Figure 2. Total reducing ability (TRA) in sliced Hanwoo (Korean cattle) beef loin in packaging systems for $14 \mathrm{~d}$ at $4^{\circ} \mathrm{C}$. Data are presented as means \pm SD. VACP, vacuum packaging; MOMAP, medium oxygen-modified atmosphere packaging $\left(50 \% \quad \mathrm{O}_{2} / 20 \%\right.$ $\mathrm{CO}_{2} / 30 \% \mathrm{~N}_{2}$ ) alone; VSP-MOMAP, MOMAP combined with vacuum skin packaging; HOMAP, high oxygen-MAP $(80 \%$ $\mathrm{O}_{2} / 20 \% \mathrm{CO}_{2} / 0 \% \mathrm{~N}_{2}$ ) alone; VSP-HOMAP: HOMAP combined with VSP; SD, standard deviation. exposure to higher $\mathrm{O}_{2}$ atmosphere.

\section{Total reducing ability}

There were significant effects of packaging system $(p<0.001)$, storage time $(p<0.001)$, and their interaction $(\mathrm{p}<0.001)$ on the TRA in the sliced beef loin (Table 1). A decrease $(p<0.05)$ in TRA was found in the sliced beef stored under all packaging systems during storage (Figure $2)$. The sliced beef stored under VACP had higher $(\mathrm{p}<0.05)$ TRA than the beef stored under the other packaging systems for $14 \mathrm{~d}$ of storage. Combination with $\mathrm{O}_{2}$-MAP and VSP gave a tendency to maintain higher TRA in the stored-sliced beef than $\mathrm{O}_{2}$-MAP alone. However, the sliced beef stored under VSP-MOMAP had higher $(p<0.05)$ TRA than the beef stored under HOMAP from $7 \mathrm{~d}$ and indicated higher $(p<0.05)$ TRA than the beef stored under VSP-HOMAP at $d$ 14. Liu et al. (2014) reported similar results where the beef steak stored under VACP or carbon monoxide-MAP had higher TRA compared with the steak stored under HOMAP for $14 \mathrm{~d}$. The decreased TRA in the higher $\mathrm{O}_{2}$ packaging system may be due to consumption of reducing components for oxymyoglobin stabilization (Seyfert et al., 2007) or destruction of endogenous antioxidants, such as vitamins, thiols, polyamines, and peptides, by oxidation process (Decker et al., 2000; Clausen et al., 2009).

\section{2-Thiobarbituric acid reactive substances content}

In the sliced beef loin, packaging system $(p<0.001)$, storage time $(p<0.001)$, and their interaction $(p<0.001)$ had significant effects on TBARS content (Table 1). During

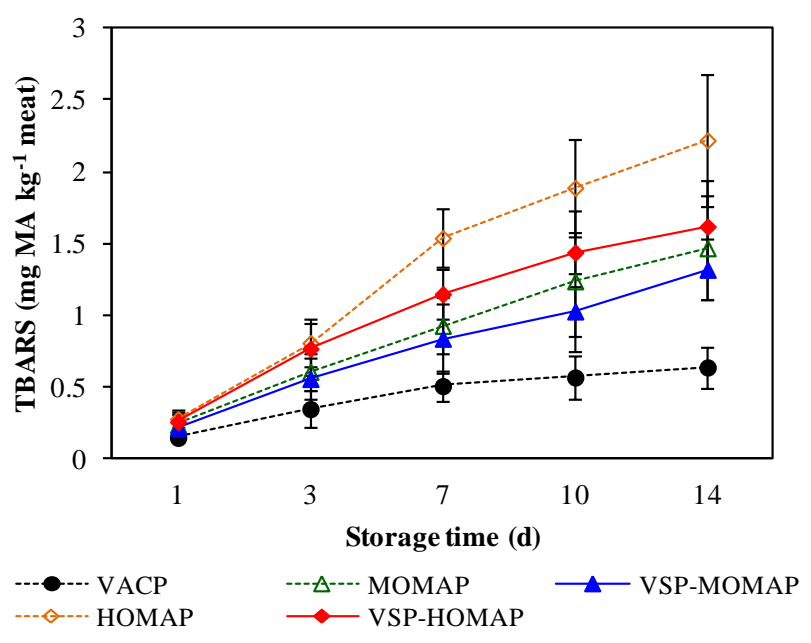

Figure 3. TBARS content in sliced Hanwoo (Korean cattle) beef loin in packaging systems for $14 \mathrm{~d}$ at $4^{\circ} \mathrm{C}$. Data are presented as means \pm SD. TBARS, 2-thiobarbituric acid reactive substances; VACP, vacuum packaging; MOMAP, medium oxygen-modified atmosphere packaging $\left(50 \% \quad \mathrm{O}_{2} / 20 \% \quad \mathrm{CO}_{2} / 30 \% \quad \mathrm{~N}_{2}\right)$ alone; VSPMOMAP, MOMAP combined with vacuum skin packaging; HOMAP, high oxygen-MAP $\left(80 \% \quad \mathrm{O}_{2} / 20 \% \quad \mathrm{CO}_{2} / 0 \% \quad \mathrm{~N}_{2}\right)$ alone; VSP-HOMAP, HOMAP combined with VSP; SD, standard deviation. 
storage, a sharp increase $(\mathrm{p}<0.05)$ in TBARS content was observed in the sliced beef stored under all packaging systems (Figure 3). The sliced beef stored under VACP maintained lower $(p<0.05)$ TBARS content for $14 \mathrm{~d}$ of storage compared with the beef stored under the other packaging systems. From $7 \mathrm{~d}$, the sliced beef stored under MOMAP, VSP-MOMAP, and VSP-HOMAP had lower $(p<0.05)$ TBARS content than the beef stored under HOMAP. This result is in agreement with a report of O'Grady et al. (2000) who found that a higher $\mathrm{O}_{2}$ packaging system increased the TBARS content in the minced beef for 10 d. In addition, Franco et al. (2012) also reported that the beef steak stored under VACP had lower TBARS content for $10 \mathrm{~d}$ compared with the steak stored under HOMAP. In the present study, packaging together with VSP delayed the development of TBARS in the sliced beef stored under $\mathrm{O}_{2}$ atmosphere packaging. This could be attributed to the fact that VSP blocked the direct exposure of beef to $\mathrm{O}_{2}$ atmosphere.

\section{Carbonyl content}

Packaging system $(\mathrm{p}<0.01)$, storage time $(\mathrm{p}<0.001)$, and their interaction $(p<0.05)$ had significant effects on the carbonyl content, measured as an index of protein oxidation, in the sliced beef loin (Table 1). Carbonyl content increased $(\mathrm{p}<0.05)$ in the sliced beef stored under all packaging systems during storage (Figure 4). In our results, the sliced beef stored under VACP, MOMAP, and VSP-MOMAP showed a tendency to have lower carbonyl content compared with the beef stored under HOMAP for $14 \mathrm{~d}$. However, at only d 7 of storage, there were significant

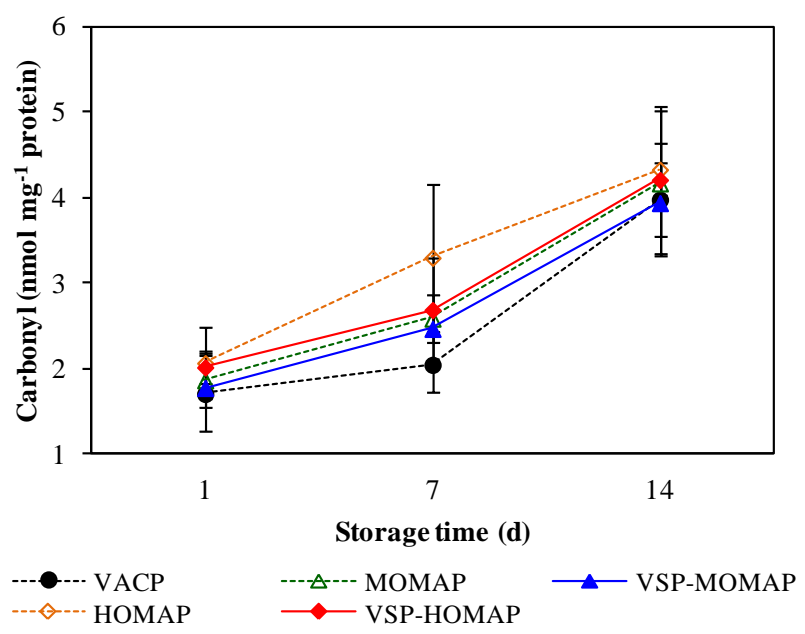

Figure 4. Carbonyl content in sliced Hanwoo (Korean cattle) beef loin in packaging systems for $14 \mathrm{~d}$ at $4{ }^{\circ} \mathrm{C}$. Data are presented as means \pm SD. VACP, vacuum packaging; MOMAP, medium oxygen-modified atmosphere packaging $\left(50 \% \quad \mathrm{O}_{2} / 20 \% \quad \mathrm{CO}_{2} / 30 \%\right.$ $\mathrm{N}_{2}$ ) alone; VSP-MOMAP, MOMAP combined with vacuum skin packaging; HOMAP, high oxygen-MAP $\left(80 \% \quad \mathrm{O}_{2} / 20 \% \quad \mathrm{CO}_{2} / 0 \%\right.$ $\mathrm{N}_{2}$ ) alone; VSP-HOMAP, HOMAP combined with VSP; SD, standard deviation. $(\mathrm{p}<0.05)$ differences in carbonyl content among the storage systems. The generation of protein carbonyls in the meat products is initiated and accelerated by lipid oxidation (Butterfield and Stadtman, 1997; Xiong, 2000). To explain in more detail, following the creation of radicals from protein or amino acids (arginine, cysteine, histidine, lysine, methionine, proline, serine, tryptophan, and valine) by attack of hydroxyl radicals $(\cdot \mathrm{OH})$ produced during the oxidation process of unsaturated fatty acids, a peroxy radical product is created by reaction with former radicals and oxygen and then finally develops carbonyls through further oxidative processes with reactive oxygen species or metal ions. Thus, a rapid increase in lipid oxidation by higher $\mathrm{O}_{2}$ packaging may promote the generation of carbonyls and this increase in carbonyl content with lipid oxidation appeared at d 7 of storage in our study. This is supported by a previous study of Lund et al. (2007a) who reported that beef patties stored under HOMAP had higher carbonyl and TBARS contents at $6 \mathrm{~d}$ compared with the patties stored under $100 \% \mathrm{~N}_{2}$-MAP. Furthermore, our result at d 14 of storage is similar with another finding of Lund et al. (2007b) who reported that the carbonyl content was not different between sliced meat stored under either HOMAP and VSP at d 14. They explained that this phenomenon is because of the advanced reaction of carbonyls. According to Xiong and Decker (1995), carbonyls cause the cross-linking of proteins, resulting in aggregation, polymerization, and insolubilization, via formation of Schiff base with free amino acids. Our result may be due to their proven mechanism and is also supported by a study of Lund et al. (2007b) who observed higher protein cross-linkage in HOMAP compared with VSP.

\section{Instrumental meat color}

Red color, determined with CIE $\mathrm{a}^{*}$ value, in the sliced beef loin was influenced by packaging system $(p<0.001)$, storage time $(\mathrm{p}<0.001)$, and their interaction $(\mathrm{p}<0.001)$ (Table 1). During storage, the $\mathrm{a}^{*}$ value rapidly decreased $(\mathrm{p}<0.05)$ in the sliced beef stored under Ox-MAP, but little changed in the beef stored under VACP (Figure 5). Compared with the sliced beef stored under the other packaging systems, the beef stored under VACP had lower $(\mathrm{p}<0.05) \mathrm{a}^{*}$ value up to $3 \mathrm{~d}$ of storage and further storage to $14 \mathrm{~d}$ resulted in higher $(\mathrm{p}<0.05) \mathrm{a}^{*}$ value. From $7 \mathrm{~d}$ of storage, the sliced beef stored under VSP-MOMAP presented a higher $\mathrm{a}^{*}$ value than the beef stored under both HOMAP, and VSP-HOMAP. Moreover, it had higher $(p<0.05) a^{*}$ value than the beef stored under MOMAP from $10 \mathrm{~d}$ of storage. The sliced beef stored under VSPHOMAP indicated a tendency to have higher $\mathrm{a}^{*}$ value than the beef stored under HOMAP during storage. Lindahl (2011) also observed the deterioration of red color in the beef steak stored under HOMAP. In a previous study by Li 


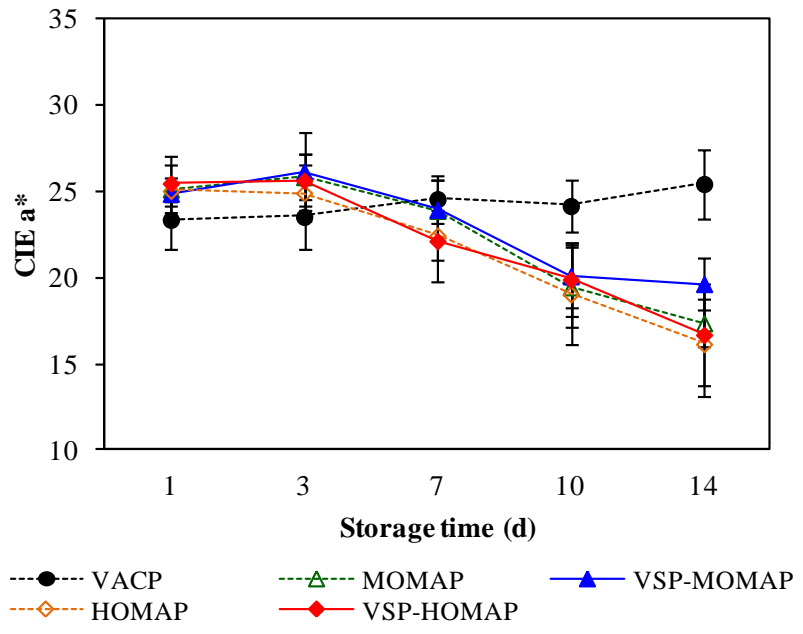

Figure 5. CIE a* value in sliced Hanwoo (Korean cattle) beef loin in packaging systems for $14 \mathrm{~d}$ at $4{ }^{\circ} \mathrm{C}$. Data are presented as means \pm SD. CIE, Commission Internationale de l'Eclairage; VACP, vacuum packaging; MOMAP, medium oxygen-modified atmosphere packaging $\left(50 \% \quad \mathrm{O}_{2} / 20 \% \quad \mathrm{CO}_{2} / 30 \% \quad \mathrm{~N}_{2}\right)$ alone; VSPMOMAP, MOMAP combined with vacuum skin packaging; HOMAP, high oxygen-MAP $\left(\begin{array}{llll}80 \% & \mathrm{O}_{2} / 20 \% & \mathrm{CO}_{2} / 0 \% & \mathrm{~N}_{2}\end{array}\right)$ alone; VSP-HOMAP, HOMAP combined with VSP; SD, standard deviation.

et al. (2012), a similar finding of maintenance of red color in the sliced beef stored under VSP has been reported. In the stored fresh meat, the decrease of red color is caused by oxidation of oxymyoglobin to metmyoglobin and is elevated by lipid oxidation (Faustman et al., 2010). In the present study, higher $\mathrm{O}_{2}$ packaging accelerated the deterioration of red color in the sliced beef but VSP retarded the decrease of red color by $\mathrm{O}_{2}$ atmosphere. Thus, this result may be related with different developments of TBARS by packaging systems.

\section{Nonheme iron content}

Significant effects of packaging system $(p<0.01)$ storage time $(p<0.001)$, and their interaction $(p<0.05)$ on the nonheme iron content were found in the sliced beef loin (Table 1). Nonheme iron content increased $(p<0.05)$ in the sliced beef stored under all packaging systems at d 14 of storage (Figure 6). At the same storage time, the sliced beef stored under VACP had lower $(\mathrm{p}<0.05)$ nonheme iron content compared with the beef stored under the other packaging systems. Moreover, the beef stored under VSPMOMAP had lower $(\mathrm{p}<0.05)$ nonheme iron content than the beef stored under HOMAP. Nonheme iron, i.e. free ion, is created by reaction of metmyoglobin with lipid hydroperoxides or $\mathrm{H}_{2} \mathrm{O}_{2}$ and has a direct relationship with lipid oxidation because of initiation and propagation by production of free radicals through Penton's reaction (Harel and Kanner, 1985; Reeder and Wilson, 1998; Min and Ahn, 2005; Muhlisin et al., 2013). Thus, based on our results with

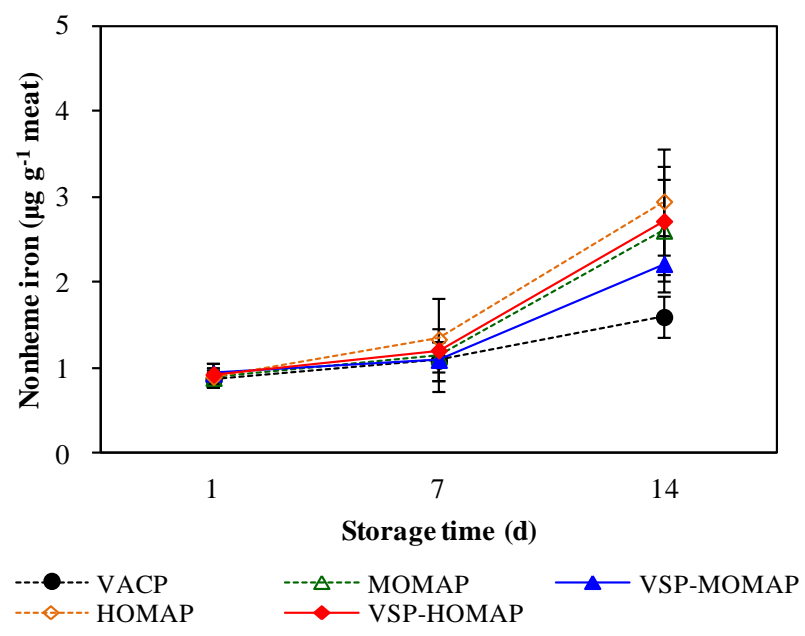

Figure 6. Nonheme iron content in sliced Hanwoo (Korean cattle) beef loin in packaging systems for $14 \mathrm{~d}$ at $4^{\circ} \mathrm{C}$. Data are presented as means \pm SD. VACP, vacuum packaging; MOMAP, medium oxygen-modified atmosphere packaging $\left(50 \% \quad \mathrm{O}_{2} / 20 \% \quad \mathrm{CO}_{2} / 30 \%\right.$ $\mathrm{N}_{2}$ ) alone; VSP-MOMAP, MOMAP combined with vacuum skin packaging; HOMAP, high oxygen-MAP $\left(80 \% \quad \mathrm{O}_{2} / 20 \% \quad \mathrm{CO}_{2} / 0 \%\right.$ $\mathrm{N}_{2}$ ) alone; VSP-HOMAP, HOMAP combined with VSP; SD, standard deviation.

this mechanism, the nonheme iron content in the storedsliced beef may be highly correlated with activities of antioxidant enzymes, TRA, meat redness and degree of lipid oxidation as affected by packaging systems.

In conclusion, we confirmed the activity of antioxidant enzyme, and lipid and protein oxidation, and color stabilities in sliced Hanwoo beef loin in various packaging systems during chill storage. The VACP had the most positive effects on the stored-sliced beef loin among the packaging systems. However, VSP-MOMAP maintained higher oxidation and red color stabilities by supporting higher activity of some endogenous antioxidant enzyme and higher reducing ability compared with MOMAP, HOMAP, and VSP-HOMAP.

\section{ACKNOWLEDGMENTS}

This study was supported by 2014 year Postdoctoral Fellowship Program (Project No. PJ010170012014) of National Institute of Animal Science, Rural Development Administration, Republic of Korea.

\section{REFERENCES}

Aebi, H. E. 1983. Catalase. In: Methods of Enzymatic Analysis. (Eds. H. U. Bergmeyer, J. Bergmeyer, and M. Graß1). Verlag Chemie GmbH, Weinheim, Germany. pp. 273-286.

Avilés, C., M. Juárez, I. L. Larsen, A. Rodas-González, and J. L. Aalhus. 2014. Effect of multiple vacuum packs on colour development and stability in beef steaks. Meat Sci. 96:124.

Barros-Velázquez, J., L. Carreira, C. Franco, B. I. Vázquez, C. 
Fente, and A. Cepeda. 2003. Microbiological and physicochemical properties of fresh retail cuts of beef packaged under an advanced vacuum skin system and stored at $4^{\circ}$ C. J. Food Prot. 66:2085-2092.

Borch, E., M. L. Kant-Muermans, and Y. Blixt. 1996. Bacterial spoilage of meat and cured meat products. Int. J. Food Microbiol. 33:103-120.

Butterfiled, D. A. and E. R. Stadtman. 1997. Protein oxidation processes in aging brain. Adv. Cell Aging Gerontol. 2:161-191.

Carter, P. 1971. Spectrophotometric determination of serum iron at the submicrogram level with a new reagent (ferrozine). Anal. Biochem. 40:450-458.

Chan, K. M. and E. A. Decker. 1994. Endogenous skeletal muscle antioxidants. Crit. Rev. Food Sci. Nutr. 34:403-426.

Chen, T., G. H. Zhou, X. L. Xu, G. M. Zhao, and C. B. Li. 2010. Phospholipase A2 and antioxidant enzyme activities in normal and PSE pork. Meat Sci. 84:143-146.

Clausen, I., M. Jakobsen, P. Ertbjerg, and N. T. Madsen. 2009. Modified atmosphere packaging affects lipid oxidation, myofibrillar fragmentation index and eating quality of beef. Packag. Technol. Sci. 22:85-96.

Davis, M. J. and R. T. Dean. 2003. Radical-mediated protein oxidation. Oxford Science Univ., London, England. pp. 215.

Decker, E. A., S. A. Livisay, and S. Zhou. 2000. Mechanisms of endogenous skeletal muscle antioxidants: chemical and physical aspects. In: Antioxidants in Muscle Foods: Nutritional Strategies to Improve Quality. (Ed. E. A. Decker, C. Faustman and C. J. Lopez-Bote). John Wiley \& Sons, Inc., NY, USA. pp. 25-60.

Faustman, C., Q. Sun, R. Mancini, and S. P. Suman. 2010. Myoglobin and lipid oxidation interactions: Mechanistic bases and control. Meat Sci. 86:86-94.

Flohé, L. and W. A. Günzler. 1984. Assays of glutathione peroxidase. In: Methods Enzymol. (Ed. L. Packer). Academic Press, Inc., London, UK. pp. 114-121.

Franco, D., L. González, E. Bispo, A. Latorre, T. Moreno, J. Sineiro, M. Sánchez, and M. J. Núñez. 2012. Effects of calf diet, antioxidants, packaging type and storage time in beef steak storage. Meat Sci. 90:871-880.

Gheisari, H. R. and H. Motamedi. 2010. Chloride salt type/ionic strength and refrigeration effects on antioxidant enzymes and lipid oxidation in cattle, camel and chicken meat. Meat Sci. 86:377-383.

Gill, C. O. and J. C. L. Harrison. 1989. The storage life of chilled pork packaged under carbon dioxide. Meat Sci. 26:313-324.

Harel, S. and J. Kanner. 1985. Muscle membranal lipid peroxidation initiated by $\mathrm{H}_{2} \mathrm{O}_{2}$-activated metmyoglobin. J. Agric. Food Chem. 33:1188-1192.

Jakobsen, M. and G. Bertelsen. 2000. Colour stability and lipid oxidation of fresh beef. Development of a response surface model for predicting the effects of temperature, storage time, and modified atmosphere composition. Meat Sci. 54:49-57.

Jayasingh, P., D. P. Cornforth, C. E. Carpenter, and D. Whittier. 2001. Evaluation of carbon monoxide treatment in modified atmosphere packaging or vacuum packaging to increase color stability of fresh beef. Meat Sci. 59:317-324

Kang, S. M., Muhlisin, G. Y. Kim, S. Cho, B. Park, S. Jung, and S. K. Lee. 2012. Relationship of antioxidant enzyme activity, lipid oxidation, and aroma pattern of Hanwoo (Korean cattle) beef under oxidation-promoted condition. Korean J. Food Sci. Ani. Resour. 32:346-353.

Lagerstedt, Å., M. L. Ahnström, and K. Lundström. 2011. Vacuum skin pack of beef - A consumer friendly alternative. Meat Sci. 88:391-396.

Lee, M., R. G. Cassens, and O. R. Fennema. 1981. Effect of meat ions on residual nitrite. J. Food Proc. Preserv. 5:191-205.

Lee, S. K., L. Mei, and E. A. Decker. 1996. Lipid oxidation in cooked turkey as affected by added antioxidant enzymes. J. Food Sci. 61:726-728.

Li, X., G. Lindahl, G. Zamaratskaia, and K. Lundström. 2012. Influence of vacuum skin packaging on color stability of beef longissimus lumborum compared with vacuum and highoxygen modified atmosphere packaging. Meat Sci. 92:604-609.

Lindahl, G. 2011. Colour stability of steaks from large beef cuts aged under vacuum or high oxygen modified atmosphere. Meat Sci. 87:428-435.

Liu, C., Y. Zhang, X. Yang, R. Liang, Y. Mao, X. Hou, X. Lu, and X. Luo. 2014. Potential mechanisms of maintaining color stability of different bovine muscles. Meat Sci. 97:189-196.

Lopez-Lorenzo, P., P. Hernandez, B. Sanz-Perez, and J. A. Ordoñez. 1980. Effect of oxygen- and carbon dioxide-enriched atmospheres on shelf-life extension of refrigerated ground pork. Meat Sci. 4:89-94

Lund, M. N., M. S. Hviid, and L. H. Skibsted. 2007a. The combined effect of antioxidants and modified atmosphere packaging on protein and lipid oxidation in beef patties during chill storage. Meat Sci. 76:226-233.

Lund, M. N., R. Lametsch, M. S. Hviid, O. N. Jensen, and L. H. Skibsted. 2007b. High-oxygen packaging atmosphere influences protein oxidation and tenderness of porcine longissimus dorsi during chill storage. Meat Sci. 77:295-303.

Marklund, S. L. 1986. Pyrogallol autooxidation. In: CRC Handbook of Methods for Oxygen Radical Research (Ed. R. A. Green). CRC Press, Boca Raton, USA. pp. 243-247.

Mei, L., A. D. Crum, and E. A. Decker. 1994. Development of lipid oxidation and inactivation of antioxidant enzymes in cooked pork and beef. J. Food Lipids 1:273-283.

Mercier, Y., P. Gatellier, M. Viau, H. Remignon, and M. Renerre. 1998. Effect of dietary fat and vitamin E on colour stability and on lipid and protein oxidation in turkey meat during storage. Meat Sci. 48:301-318.

Mercier, Y., P. Gatellier, and M. Renerre. 2004. Lipid and protein oxidation in vitro, and antioxidant potential in meat from Charolais cows finished on pasture or mixed diet. Meat Sci. 66:467-473.

Min, B and D. U. Ahn. 2005. Mechanism of lipid oxidation in meat and meat products-A review. Food Sci. Biotechnol. 14:152-163.

Morzel, M., Ph. Gatellier, T. Sayd, M. Renerre, and E. Laville. 2006. Chemical oxidation dcreases proteolytic susceptibility of skeletal muscle myofibrillar proteins. Meat Sci. 73:536-543.

Muhlisin, Y. R. Song, D. S. Kim, J. H. Lee, J. H. Choi, and S. K. Lee. 2013. Total iron, heme iron and free iron contents in raw and cooked meat of Korean native chicken, duck and Hanwoo. In: Proceedings of 2013 Annual Congress of Korean Society of Animal Sciences and Technology, Jeju, Korea. pp. 229.

O'Grady, M. N., F. J. Monahan, R. M. Burke, and P. Allen. 2000. The effect of oxygen level and exogenous $\alpha$-tocopherol on the 
oxidative stability of minced beef in modified atmosphere packs. Meat Sci. 55:39-45.

Reeder, B. J. and M. T. Wilson. 1998. Mechanism of reaction of myoglobin with the lipid hydroperoxide hydroperoxyoctadecadienoic acid. Biochem. J. 330:1317-1323.

Renerre, M., F. Dumont, and Ph. Gatellier. 1996. Antioxidant enzyme activities in beef in relation to oxidation of lipid and myoglobin. Meat Sci. 43:111-121.

Reznick, A. Z. and L. Packer. 1994. Oxidative damage to proteins: Spectrophotometric method for carbonyl assay. In: Methods Enzymol. (Ed. L. Packer). Academic Press, Inc., San Diego, CA, USA. pp. 357-363.

Santos, E. M., A. M. Diez, C. González-Fernández, I. Jaime, and J. Rovira. 2005. Microbiological and sensory changes in "Morcilla de Burgos" preserved in air, vacuum and modified atmosphere packaging. Meat Sci. 71:249-255.

Seyfert, M., R. A. Mancini, M. C. Hunt, J. Tang, and C. Faustman. 2007. Influence of carbon monoxide in package atmospheres containing oxygen on colour, reducing activity, and oxygen consumption of five bovine muscles. Meat Sci. 75:432-442.

Sinnhuber, R. O. and T. C. Yu. 1977. The 2-thiobarbituric acid reaction, an objective measure of the oxidative deterioration occurring in fats and oils. J. Jpn. Soc. Fish. Sci. 26:259-267.
Smith, G. C., K. E. Belk, J. N. Sofos, J. D. Tatum, and S. N. Williams. 2000. Economic implications of improved color stability in beef. In: Antioxidants in Muscle Foods: Nutritional Strategies to Improve Quality (Eds. E. A. Decker, C. Faustman, and C. J. Lopez-Bote). John Wiley \& Sons, Inc, NY, USA. pp. 397-426.

SPSS. 2011. PASW Statistics 21. Statistical Package for the Social Sciences Incorporated, Chicago, IL, USA.

Troy, D. J. and J. P. Kerry 2010. Consumer perception and the role of science in the meat industry. Meat Sci. 86:214-226.

Vázquez, B. I., L. Carreira, C. Franco, C. Fente, A. Cepeda, and J. B. Velázquez. 2004. Shelf life extension of beef retail cuts subjected to an advanced vacuum skin packaging system. Eur. Food Res. Technol. 218:118-122.

Xiong, Y. L. and E. A. Decker. 1995. Alterations of muscle protein functionality by oxidative and antioxidative processes. J. Muscle Foods 6:139-160.

Xiong, Y. L. 2000. Protein oxidation and implications for muscle food quality. In: Antioxidants on Muscle Foods (Eds. E. Decker, C. Faustman, and C. J. Lopez-Bote). John Wiley and Sons, Inc., NY, USA. pp. 85-111. 